\title{
Occurrence and Distribution of Stork Species in Bundelkhand Region, the Drought Prone Landscape of India
}

\author{
Sonika Kushwaha ${ }^{1}$, Akhilesh Kumar ${ }^{2}$ \\ ${ }^{1}$ President, ${ }^{2}$ Secretary \\ Indian Biodiversity Conservation Society, Jhansi, Uttar Pradesh, India
}

\begin{abstract}
Storks are large wading birds that are distributed across the Indian Sub Continent. They belong to the order Ciconiiformes, having long bills, necks and legs. The family Ciconiidae is closely associated with wetlands, marshes and swamps. The study was conducted for 3 consecutive years (January 2015 to January 2018) to know the occurrence and distribution of stork species in Bundelkhand region of India that is a drought prone landscape. Road surveys and field trips were carried following the line transect and point count methods. Bundelkhand region is privileged to put up with 6 species (5 residential and 1 migratory species) of Storks in spite of its adverse climatic conditions. The 6 species were spotted individually, in flocks and mixed flocks were also not uncommon. They were observed foraging and resting at reservoirs, rivers, seasonal ponds and also water filled in agricultural fields. The bird flocks varied seasonally. The sand mining in rivers, vanishing seasonal ponds and drastic change in agricultural practices are a serious threat to the Stork species and other wetland birds. For conserving the stork species it is vital to involve the local communities.
\end{abstract}

Key Words: Storks; Bundelkhand Region; wetlands

\section{INTRODUCTION}

Climatic and hydrological droughts are prominent in the Bundelkhand region of India (7 districts of Uttar Pradesh and 9 districts of Madhya Pradesh). The masses are living below poverty line due to the disturbance in their livelihood activities i.e. agriculture and livestock rearing. The droughts have resulted in severe scarcity of food grains and fodder and have made their lives miserable. A number of field reports state the competence Bundelkhand in gratifying its needs for the domestic and irrigation water in early 1970s all the way through traditional methods of water harvesting regardless of facing the droughts. This delicate ecological relation where forests assisted in recharging and regulating rain water flow that was stored in the huge network of tanks, ponds, and dug-wells to be used in lean periods. These storage ponds and tanks served as the recharge pits [1]. But with due course of time, the twin action of deforestation and negligence of water bodies, distorted the complete ecosystem. The reduction in water recharge has not only affected the need of water for domestic and irrigation purposes but also alarmed the population of water birds. Storks are large wading birds that are distributed across the Indian Sub Continent. They belong to the order Ciconiiformes, having long bills, necks and legs. The family Ciconiidae is closely associated with wetlands, marshes and swamps [2]. There are 19 species of storks recorded all over the world, out of which 15 are regionally threatened [3]. In India, 8 stork species have been reported [4]. Two of these species are migratory (Black stork and White stork) while the other six are residential (Asian Open-Bill, Painted stork, Woolly-Necked stork, Black-Necked stork, Lesser Adjutant and Greater Adjutant). So far no studies have been conducted on family Ciconiidae in Bundelkhand Region. For their conservation, it is important to know the status and understand the biology. The absence of baseline data hinders the path of conservation of species that are already threatened. So the study was undertaken for the reason to fill these knowledge gaps particularly in the unprotected areas.

\section{MATERIAL AND METHODS}

The study was conducted for 3 consecutive years (January 2015 to January 2018) to know the 
occurrence and distribution of stork species in 6 districts (Shivpuri, Tikamgarh and Sagar in Madhya Pradesh; Jalaun, Jhansi and Lalitpur in Uttar Pradesh) of Bundelkhand region (Fig.1). All the three seasons were covered. Road surveys and field trips were carried following the line transect and point count methods. The reservoirs were covered along with the interior ponds and river sites. The agricultural fields were mostly observed from the road sides. The observations were supported by photographic evidences using 7 D DSLR Canon camera. GPS coordinates were also taken using 20e-trex GPS recorder. The survey time was mostly the morning hours (05-10 AM in summers and 07-11 AM in winters).

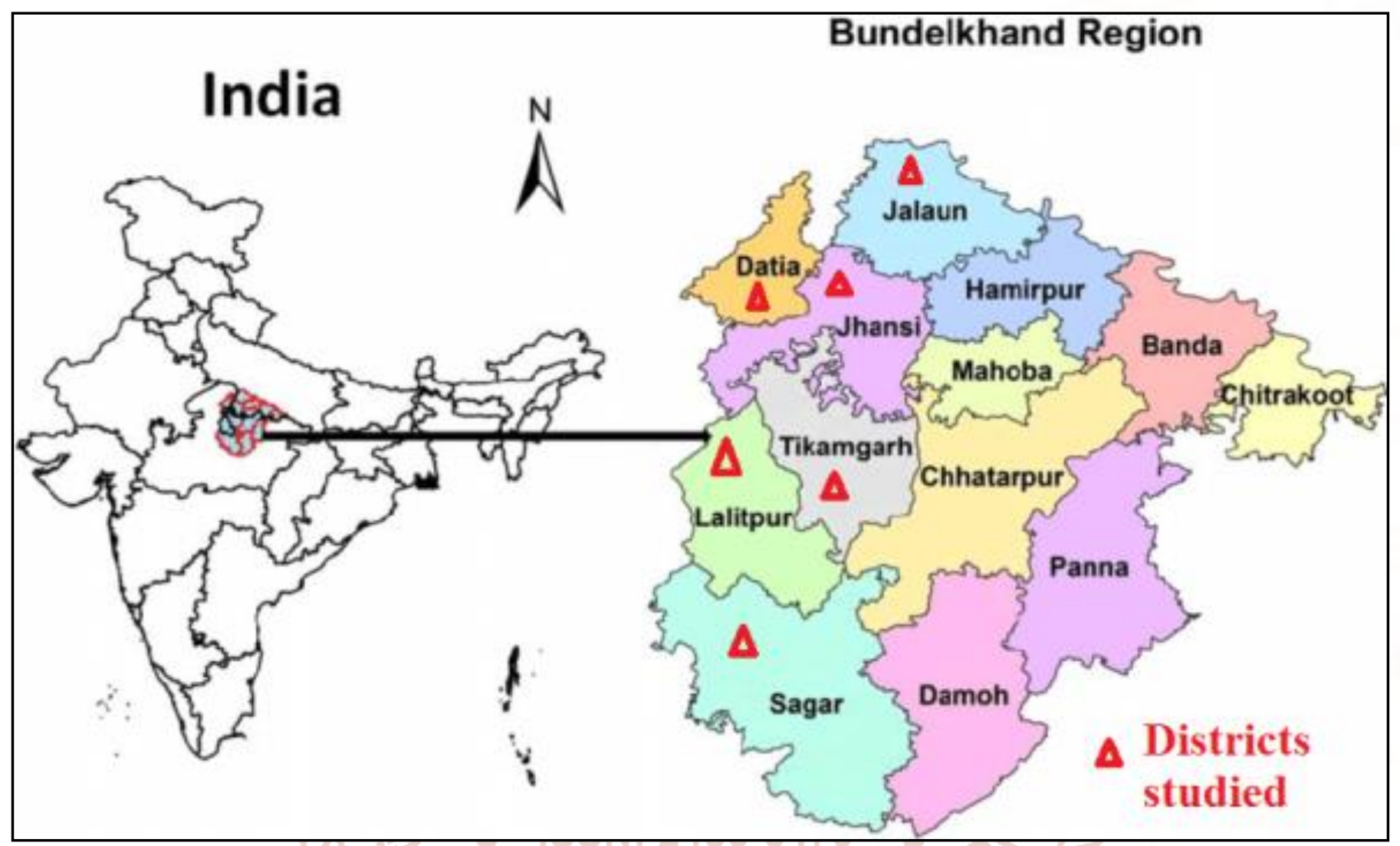

Fig.1: Study Area of Bundelkhand Region showing the 6 districts. Source [5]

\section{RESULT AND DISCUSSION}

Bundelkhand region is privileged to put up with 6 species (5 residential and 1 migratory species) of Storks in spite of its adverse climatic conditions (Table 1; Figure 2a-f). According to the IUCN Status, Woolly-Necked Stork and Lesser Adjutant are vulnerable species while Black-Necked Stork and Painted Stork are Near Threatened storks. The Asian Open-Bill Storks are Least concerned and the IUCN status of Black Stork is not known.

Table 1: Species of Storks reported from the study area [6]

\begin{tabular}{|l|l|l|l|l|}
\hline S. No & \multicolumn{1}{|c|}{ Common name } & \multicolumn{1}{|c|}{ Binomial } & Residential/ Migratory & \multicolumn{1}{|c|}{ IUCN Status } \\
\hline 1. & Asian open-bill & Anastomus oscitans & Residential & Least concern \\
\hline 2. & Woolly-necked stork & Ciconia episcopus & Residential & Vulnerable \\
\hline 3. & Black-necked stork & Ephippiorhynchus asiaticus & Residential & Near Threatened \\
\hline 4. & Lesser Adjutant & Leptoptilos javanicus & Residential & Vulnerable \\
\hline 5. & Painted stork & Mycteria leucocephala & Residential & Near Threatened \\
\hline 6. & Black stork & Ciconia nigra & Migratory & Unknown \\
\hline
\end{tabular}




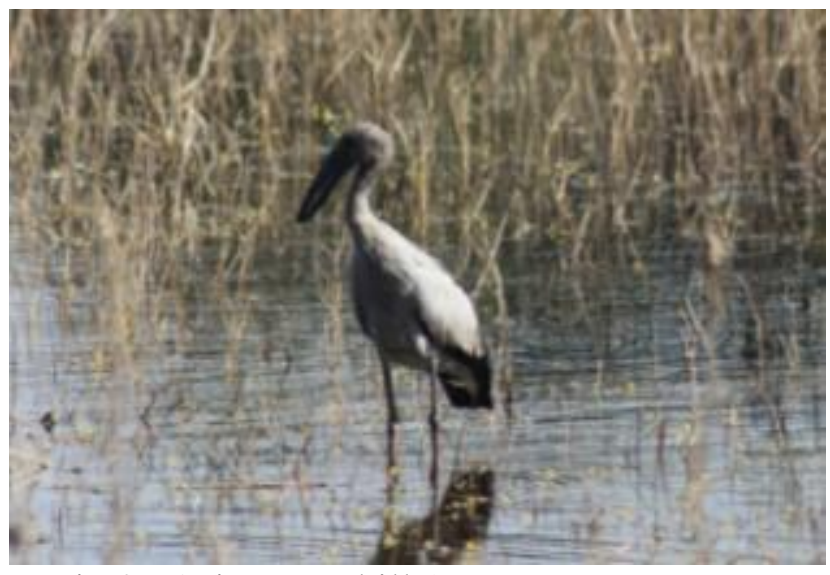

Fig.2a:Asian openbill (Anastomus oscitans)

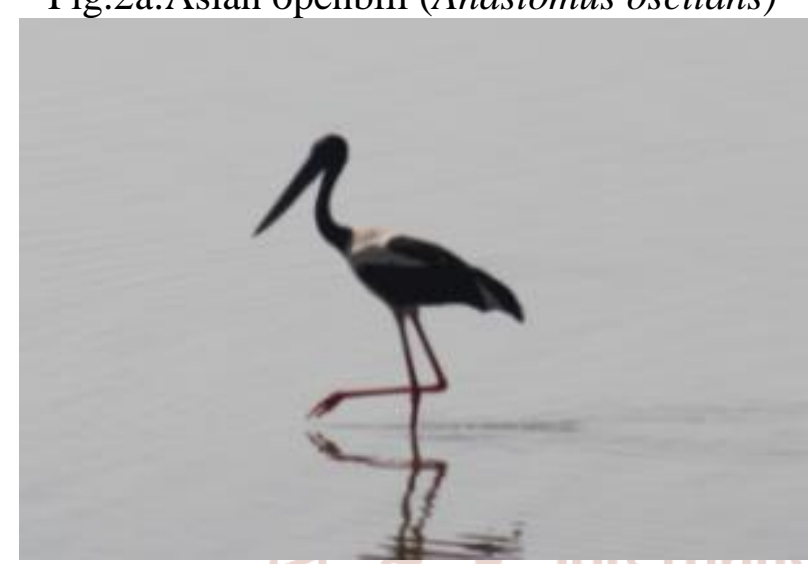

Fig.2c:Black-necked stork (Ephippiorhynchus asiaticus)

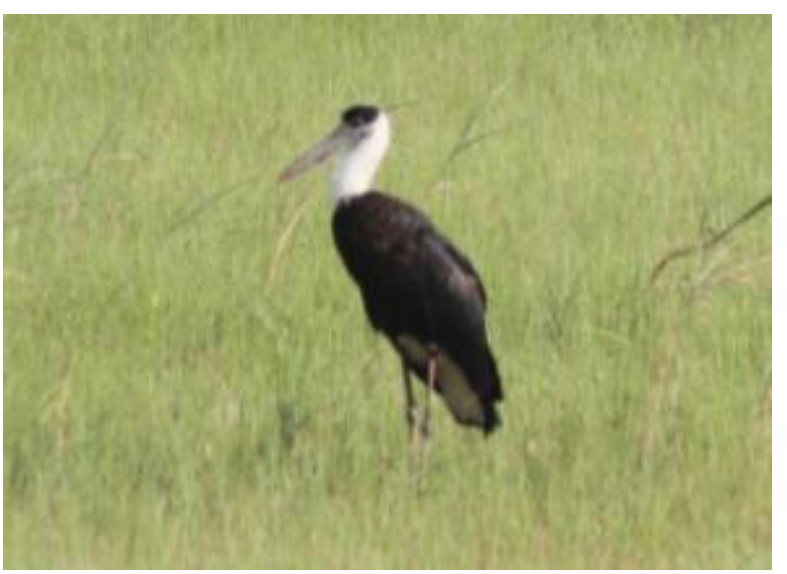

Fig.2 b:Woolly-necked stork (Ciconia episcopus)

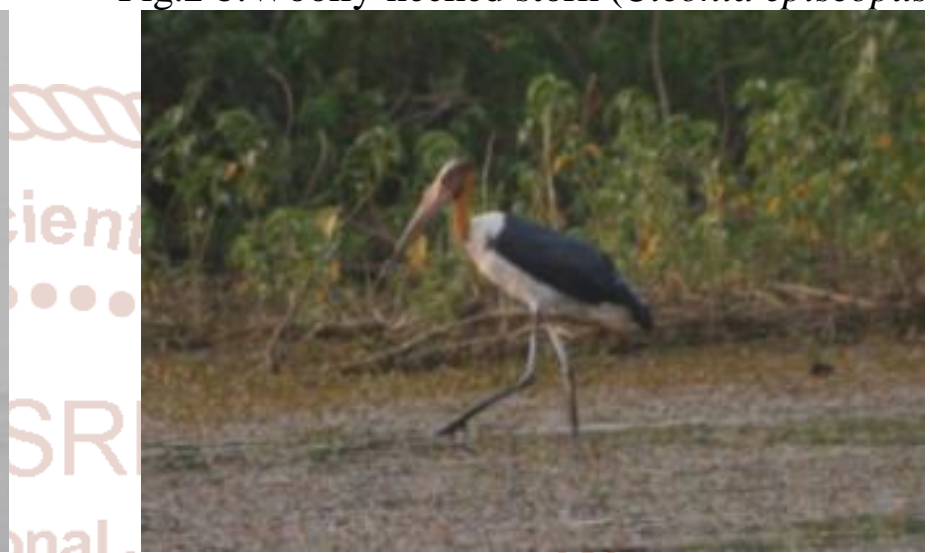

Fig. 2 d:Lesser Adjutant (Leptoptilos javanicus)

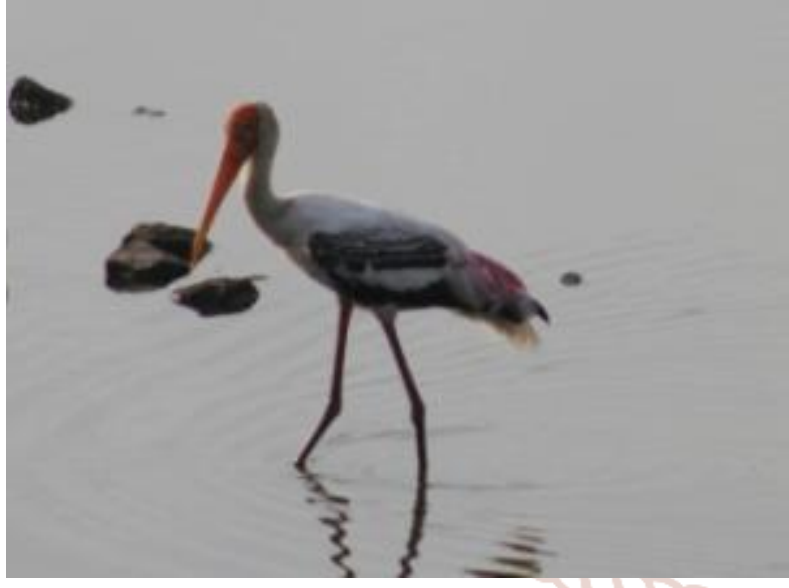

Fig.2e: Painted stork (Mycteria leucocephala)

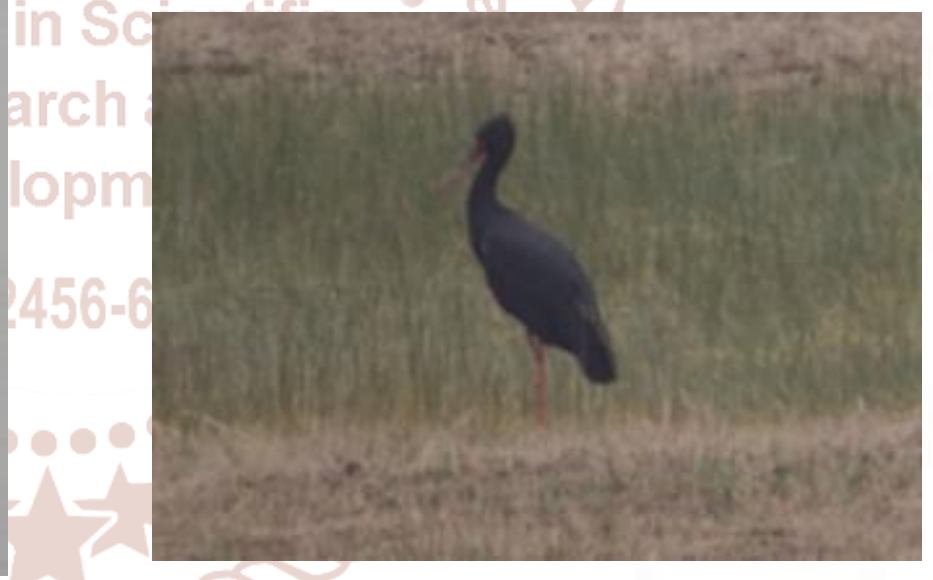

Fig.21f: Black Stork (Ciconia nigra)

\section{Fig. 1a-f: Stork Species reported in the study area}

Five species of storks (Asian open bill, Woolly necked stork, Black-necked stork, Lesser adjutant and Painted stork) occurred in all the six districts. Black stork, the migratory species was not recorded from Tikamgarh, Jalaun and Jhansi (Table 2). The storks were observed in solitude, in pairs, in flocks and in mixed flocks. The Asian Open-bill (Anastomus oscitans) was mostly observed in flocks that ranged

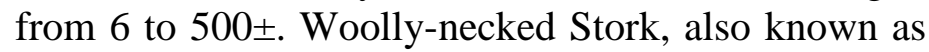
White-necked stork was mostly seen in pairs or in small flocks of 4-8 storks. On certain occasions they were seen in flocks ranging from 30-40 (Fig.3). This was mostly during the summers when water sources get limited. The black-necked storks were always seen singly or in pair. This species is illustrated as nonsocial, found largely as single birds, pairs or small family parties, and introvert in human commotion [7, 8]. Unlike the other storks, the Black-necked stork is a generalist feeder that defends its large territory. The Lesser adjutant (Leptoptilos javanicus) preferred solitude and was always seen individually. It chose to stay away from human disturbances. The Painted storks, like Woolly-necked storks were observed in small flocks comprising of 4-12 individuals. Large 
flocks of Painted storks were not located during the study. This may be attributed to the adverse climatic conditions in Bundelkhand region. The feeding behavior of Painted stork is closely associated to the environmental conditions such as presence or absence of aquatic vegetation and turbidity in water [9]. The Black storks were sighted in pair or in small flocks of maximum 6 individuals. They were also seen in mixed flocks with White-necked stork (Fig.4). Occurrence of Black Storks is inversely proportional to human activity, irrelevant of whether open habitat is available at the location. When human pressure is moderate, open habitats and low tree canopy favor the presence of Black Storks [10].

Table 2: Occurrence of Stork species in the study area

\begin{tabular}{|c|c|c|c|c|c|c|c|}
\hline S. No. & District/State & AOB & WNS & BNS & LA & PS & BS \\
\hline 1 & Shivpuri/MP & $\checkmark$ & $\checkmark$ & $\checkmark$ & $\checkmark$ & $\checkmark$ & $\checkmark$ \\
\hline 2 & Tikamgarh/MP & $\checkmark$ & $\checkmark$ & $\checkmark$ & $\checkmark$ & $\checkmark$ & X \\
\hline 3 & Sagar/MP & $\checkmark$ & $\checkmark$ & $\checkmark$ & $\checkmark$ & $\checkmark$ & $\checkmark$ \\
\hline 4 & Jalaun/UP & $\checkmark$ & $\checkmark$ & $\checkmark$ & $\checkmark$ & $\checkmark$ & X \\
\hline 5 & Jhansi/UP & $\checkmark$ & $\checkmark$ & $\checkmark$ & $\checkmark$ & $\checkmark$ & X \\
\hline 6 & Lalitpur/UP & $\checkmark$ & $\checkmark$ & $\checkmark$ & $\checkmark$ & $\checkmark$ & $\checkmark$ \\
\hline
\end{tabular}

AOB-Asian open bill; WNS-Woolly-necked stork; BNS-Black-necked stork; LA-Lesser Adjutant; PS-Painted stork; BS-Black stork

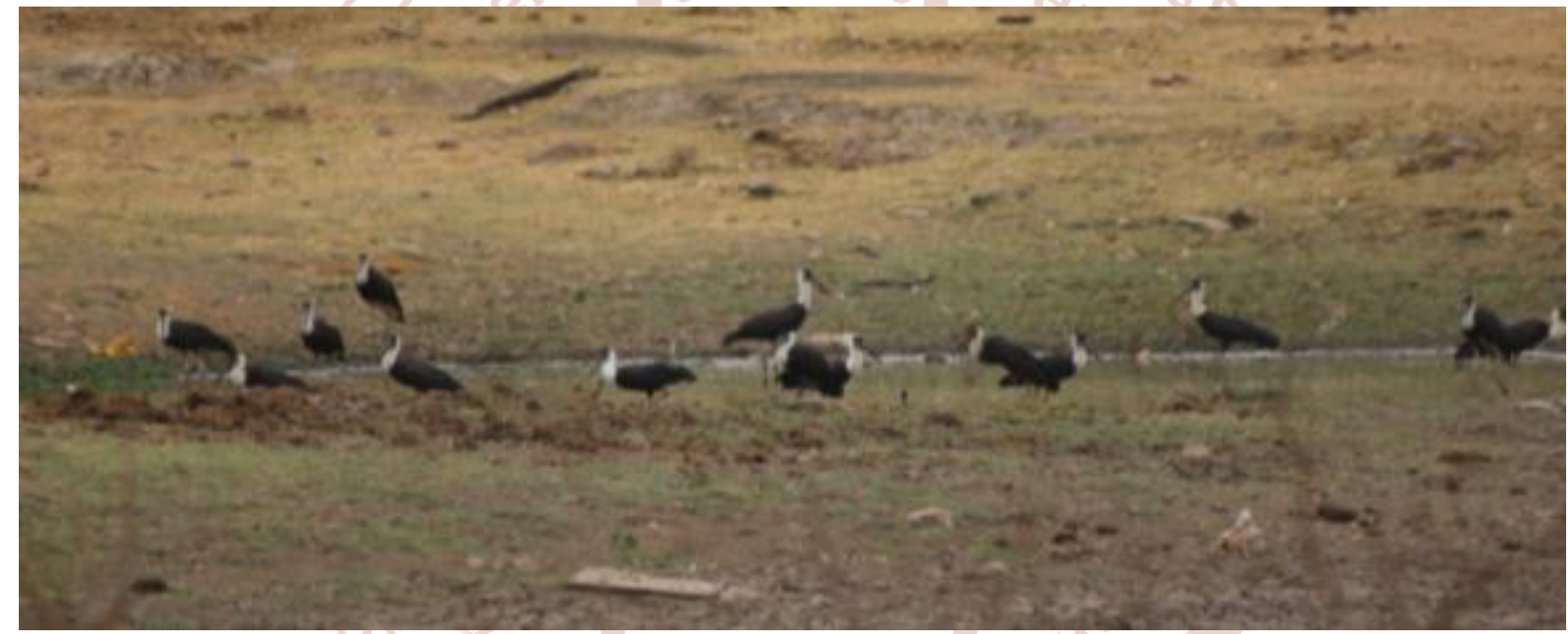

Fig.3: Flock of Woolly-necked Stork in Deogarh, Lalitpur

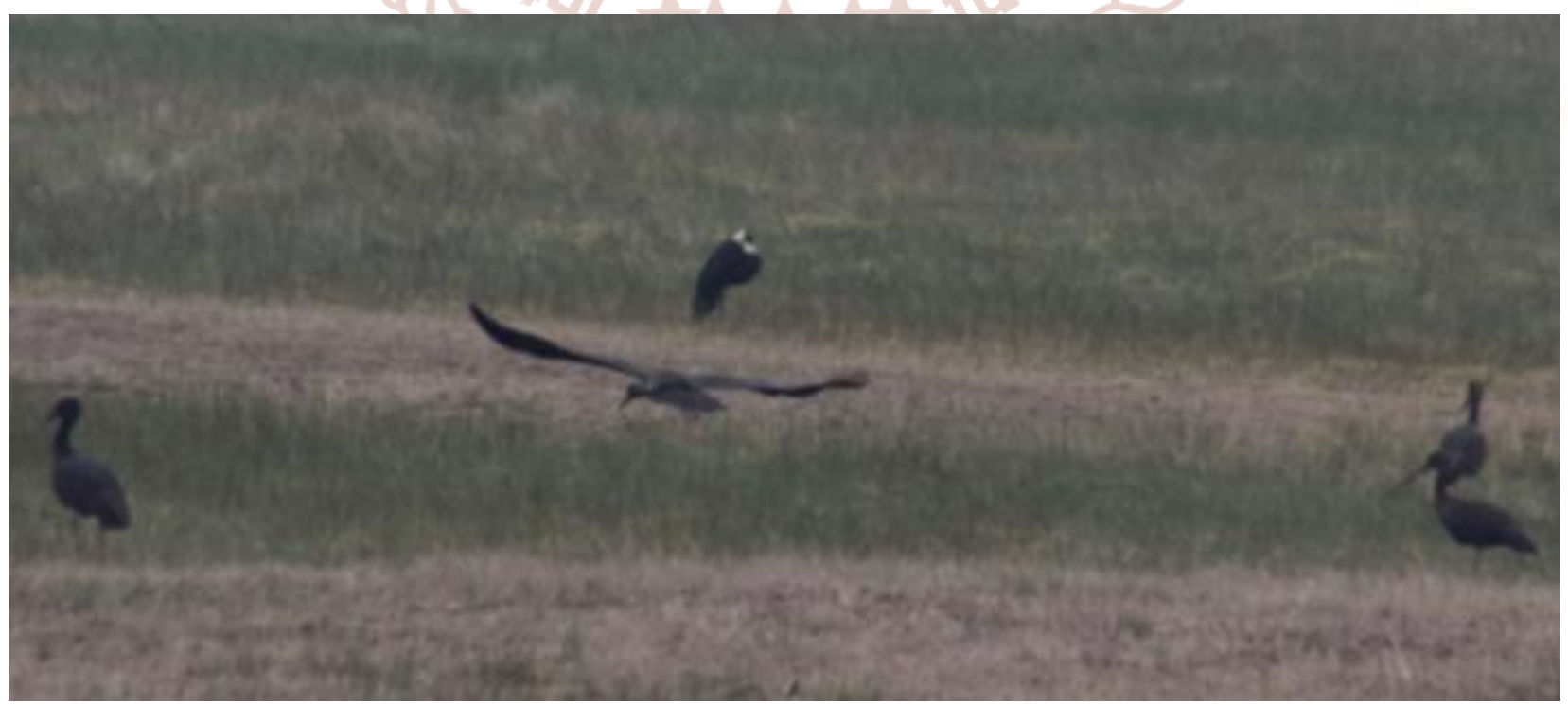

Fig.4: Flock of Black Stork with the Woolly-necked Stork 
Storks were observed foraging and resting at reservoirs, rivers, seasonal ponds and also water filled in agricultural fields (Table 3). The 6 species were spotted individually, in flocks and mixed flocks were also not uncommon. The mixed flocks of Whitenecked storks and Asian Open-bill were seen together at various sites. Similarly flocks of Painted storks and Asian Open-bill were observed during the field surveys. The bird flocks varied seasonally. The distribution of stork species was governed by the availability of food resources. Food availability is one of the imperative aspects with governs the distribution of birds to a large extent. The Asian-open bill were seen in all five types of habitats i.e. the reservoirs, ponds, rivers, agricultural fields and open fields filled with rain water (Fig.5a-d). Generally, open habitats offer very good visibility and hence the possibility for storks to see the danger coming from afar, whereas danger cannot be anticipated within closed habitats, hence increasing the risk of predation [11].

Table 3: Distribution of Stork species in different Habitats

\begin{tabular}{|l|l|c|c|c|c|c|}
\hline $\begin{array}{c}\text { S. } \\
\text { No. }\end{array}$ & \multicolumn{1}{|c|}{ Species } & Reservoir & Pond & River & $\begin{array}{c}\text { Agricultural } \\
\text { fields }\end{array}$ & $\begin{array}{c}\text { Open field } \\
\text { (water filled) }\end{array}$ \\
\hline 1. & Asian openbill & $\checkmark$ & $\checkmark$ & $\checkmark$ & $\checkmark$ & $\checkmark$ \\
\hline 2. & Woolly-necked stork & $\checkmark$ & $\checkmark$ & $\checkmark$ & $\checkmark$ & $\checkmark$ \\
\hline 3. & Black-necked stork & $\checkmark$ & $\checkmark$ & X & X & X \\
\hline 4. & Lesser Adjutant & $\checkmark$ & $\checkmark$ & $\checkmark$ & $X$ & X \\
\hline 5. & Painted stork & $\checkmark$ & $\checkmark$ & $\checkmark$ & $\checkmark$ & $\checkmark$ \\
\hline 6. & Black stork & $\checkmark$ & $\checkmark$ & X & X & X \\
\hline
\end{tabular}

$\checkmark$ Present; X Absent

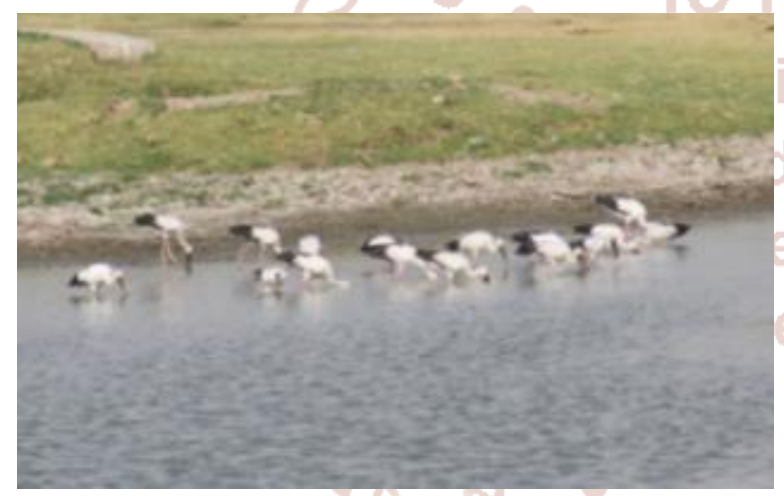

Fig.5a:Flock of Asian-Open bill at Pahuj Reservoir

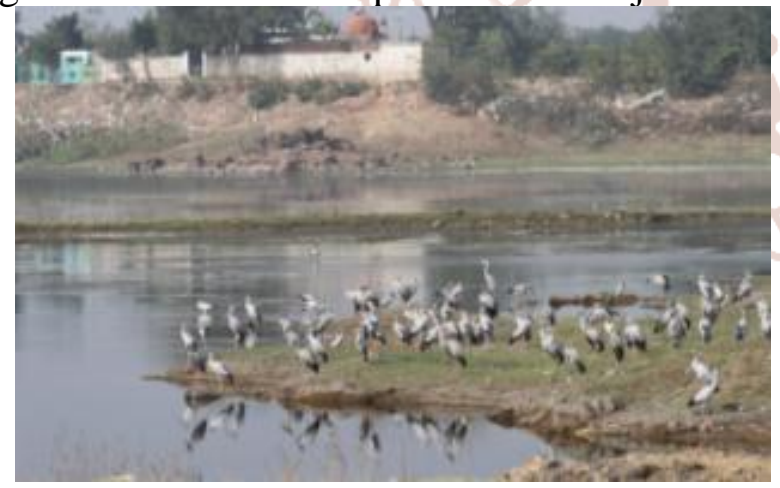

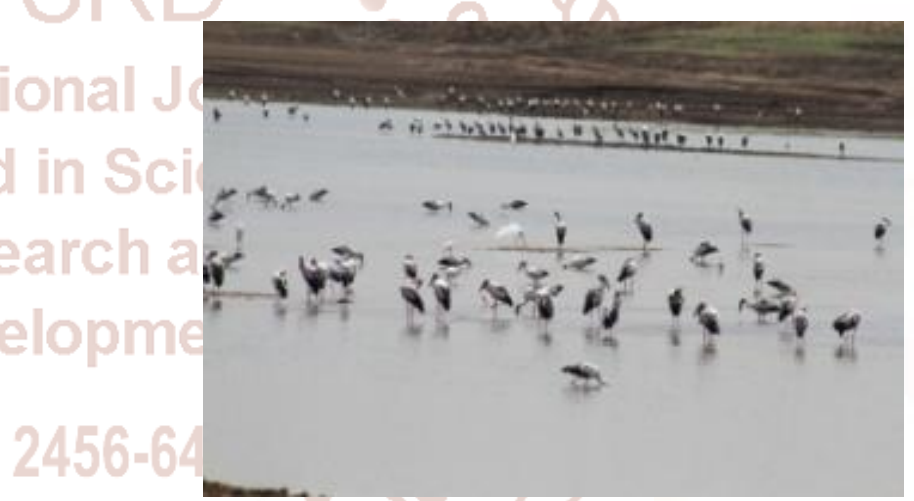

Fig.5b:Flock of Asian-Open bill along river Betwa

Fig.5c: Flock of Asian-Open bill along a pond in Jhansi Fig.5d:Flock of Asian-Open bill in agricultural field

According to [12], in an agricultural land in north India, woolly-necked storks favored fallow fields during the summer and monsoon seasons, and natural freshwater wetlands during the winter. This was in accordance with the observations during the present study where Woolly-necked storks foraged in the all the five types of habitats (Fig.6a \& 6b). The Black-necked storks were seen only along the reservoirs or ponds. They were not seen along the rivers, in Agricultural or open fields. A wide variety of wetland habitats, both freshwater and saline are known to be utilized by Black-necked Storks [4] but preference is given to wide-ranging, undisturbed, freshwater natural wetlands for foraging $[7,8]$. 


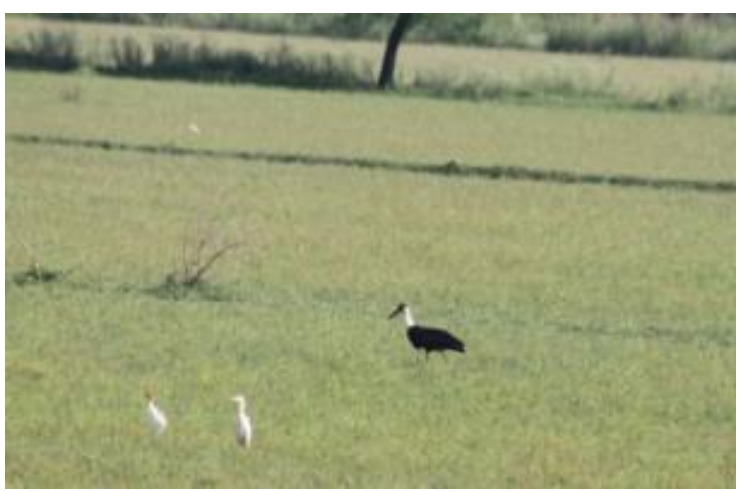

Fig.6a:Woolly-necked stork in agricultural field

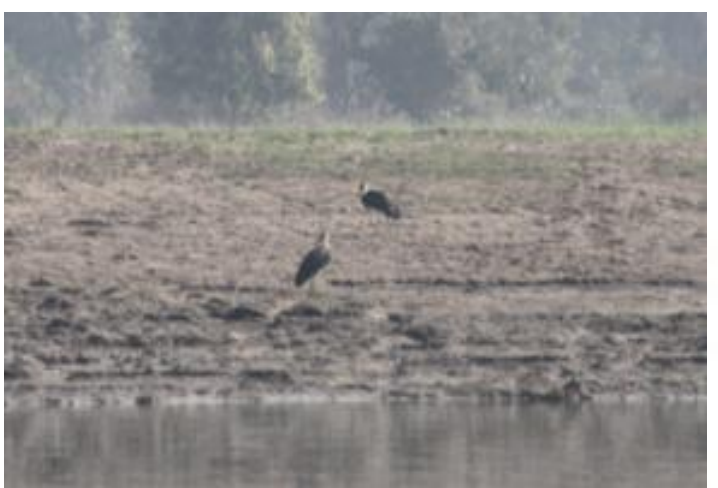

Fig.6b:Woolly-necked stork along river bank

The Lesser Adjutants were seen near natural lakes in protected and unprotected areas. They were also seen in small marshes near the rivers (Fig.7a \& b). The Lesser adjutant is habitually reported in mangrove, mudflats, coastal swamps and marshes, flooded grassland [13] although it has also been found in shallow puddles and drying ponds with plentiful fishes together with mudskippers [14]. These wetland-dependent birds occupy the riverbeds, floodplains, paddy fields, swamps, lakes and forest pools [15].

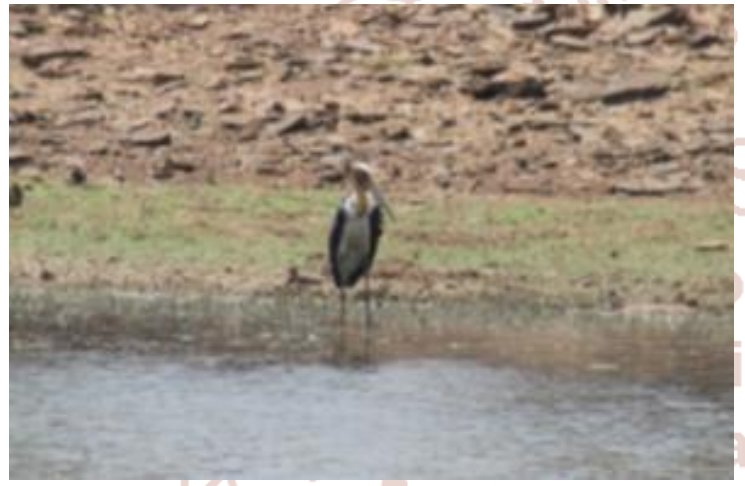

Fig.7a: Lesser Adjutant along a lake in Sagar

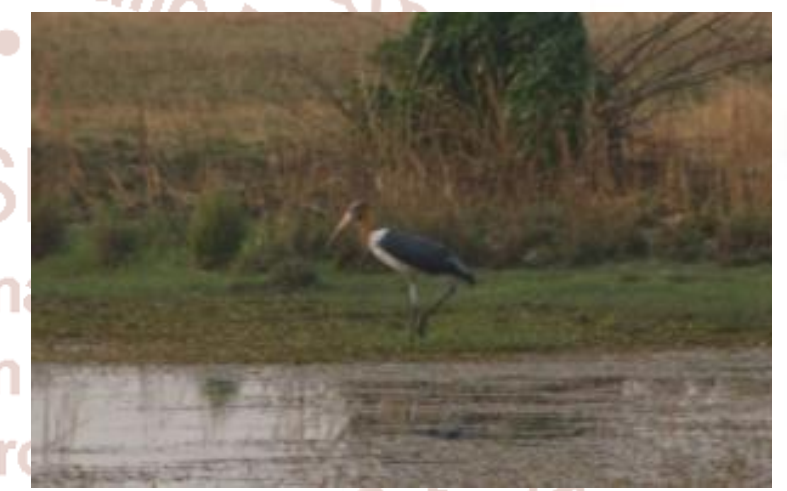

Fig.7b: Lesser Adjutant in marshy area

The Painted storks were seen foraging in all five types of habitats studied. They preferred open fields (water filled due to rains or seep out from canals) for foraging (Fig.8a \& b). The Painted stork showed negative correlation of water level with success rate and steps i.e. the success rate decreased with increase in water level. There was no competition among the three species of storks (Black-necked stork, Asian-open bill and Painted stork) due to complete separation of their niches and different levels of water depth [9]. They also shared their foraging sites with Sarus cranes, egrets and herons. Foraging in groups is advantageous for the reason that it lessens the threat of predation and, consequently, reduces the expenditure of time and energy on vigilance [16]. Although the surveys were carried out mostly during the morning times, the storks were seen in flocks during the noon also. It was observed that they spent long time in fields that included the foraging (during morning) and resting (during noon). Consistent with Gibbs, smaller species spend a longer time foraging as compared to larger bird species. Large birds exhibit normal afternoon rest periods unlike the small species.
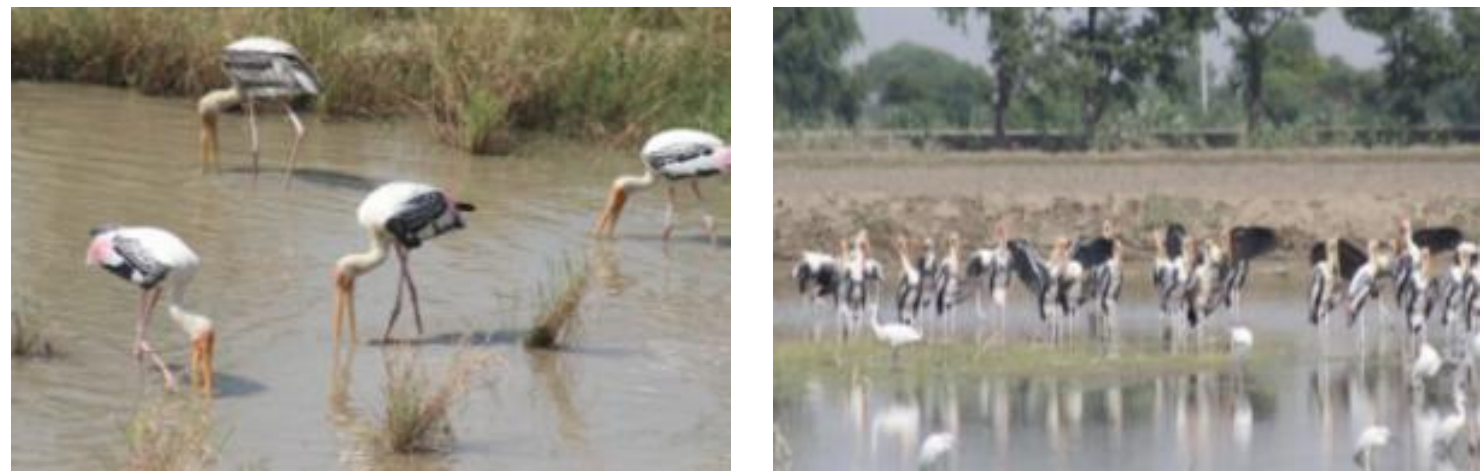

Fig.8a \& b: Painted storks foraging in open fields filled with rain water 
The Black storks were seen along the reservoirs and ponds (Fig.9a $\&$ b). They were not reported from rivers, agricultural fields and open fields in the study area. These birds are known to feed at ponds and outfalls their use of rivers is unheard of [10]. The preferred habitats by migratory Black stork are often affected by the unpredictable rainfalls in Bundelkhand Region. The droughts result in complete drying of the ponds. In the case of migrating birds, loss of habitat in wintering areas has unconstructive effects on their reproductive success and plays a key function in the turn down of their populations [17, 18].

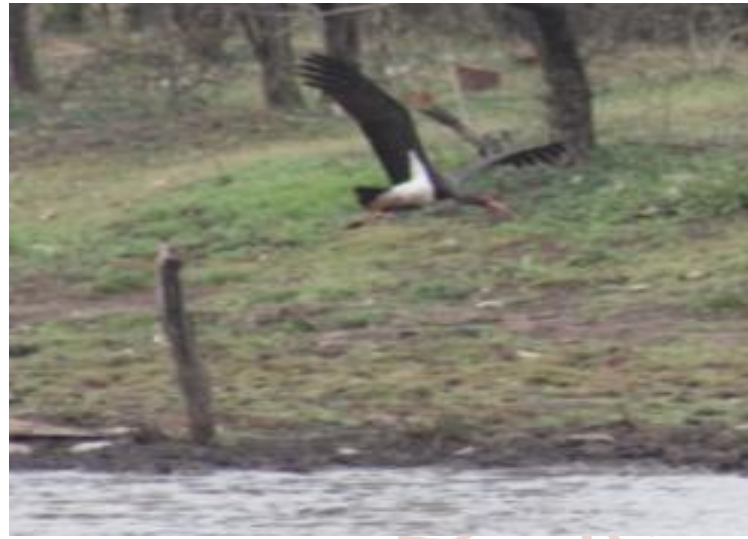

Fig.9a. Black stork around pond in shivpuri

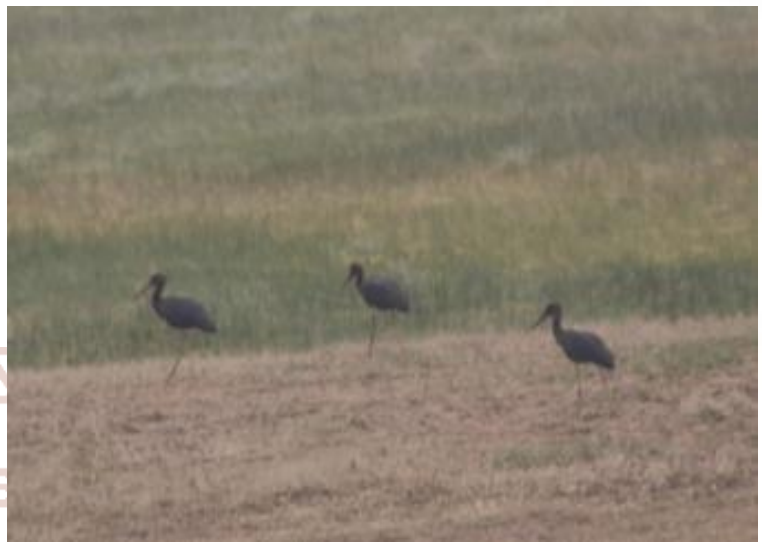

Fig.9b: Black stork around the reservoir in Lalitpur

While studying the occurrence and distribution of family Ciconiidae, some noticeable threats were also recorded. The dominating factor was vanishing of natural ponds in the rural areas. This is contributed to encroachment and sprawling of water bodies. Since Bundelkhand Region is a drought prone area, the loss of natural water bodies is a serious threat to the bird populations. Bundelkhand Region is also known for the illegal mining (Stone and sand). The contractors do not follow the rules and regulations for sand mining and leave the river beds inappropriate for the fauna. So, the sand mining in rivers, vanishing small seasonal ponds and drastic change in agricultural practices are a serious threat to the Stork species and other wetland birds in Bundelkhand Region. There are certain species, whose populations have recently declined on a large scale in Europe because of the disappearance of their foraging areas [19]. With the changing habitats due to urban sprawling, agro ecosystems, if managed wisely, can slowly but surely become essential habitats for biodiversity. For example, rice paddies endow with foraging and dispersal space for water birds as well as nesting sites for wetland associated birds like Sarus cranes. On the other hand, birds can enhance agricultural yields through pollination, seed dispersal, and even abet in improvement of plant genetic diversity [20, 21]. Many water birds such as storks, ibises, egrets and gulls explore widely both aquatic and terrestrial habitats. These birds provide dual services, one by producing guano that develops nutrient cycling and secondly they act as important control managers of agricultural pests dropping the crop loss [22, 23, 24]. The lack of knowledge and interest amongst the local residents may further contribute to loss of several species in the study area. Although the region shows potential to sustain the 6 Stork species, it is short of research work and scientific projects.

\section{CONCLUSION}

This study focused on documenting the occurrence and distribution of Stork species in Bundelkhand region of India. Documenting these is essential not only to show the diversity richness of a drought prone and economically backward region but also for further exploring research opportunities on population status, ecology and behavior of Storks. Unprecedented and unrestrained mining of rocks and sand has resulted into large scale erosion of soils and degradation of forest areas, hill slopes etc. There is an urgent requirement to frame in some policies in this regard. The habitats can also be traditionally protected and respected by the villagers, together with the employment of necessary administrative protection schemes.

\section{ACKNOWLEDGMENT}

Thanks are due to the Forest Departments of all the six districts ( 3 from Uttar Pradesh and 3 from Madhya Pradesh) for their kind co-operation during the study. We highly appreciate the assistance of local people during the survey work. Special thanks to all the volunteers without whom the field exercise would not have been easy. 


\section{REFERENCES}

1. IWRM for Rehabilitation of Bundelkhand Region of Uttar Pradesh, 2009.

2. J.R.B Alfred, A. Kumar, P.C. Tak, and J.P. Sati, "Waterbirds of Northern India", Rec. zool. Surv. India. Oce. Paper No. 190, i-xxiv, pp. 1-227, 2002.

3. M.P. Kahl, "Recent breeding records of storks in East Africa", J. East Afr.Nat.His.Soc.Natl.Mus.27, pp.67-72, 1968.

4. S. Ali, and S. D. Ripley, Birds of India and Pakistan. Oxford University Press. New Delhi, 1987.

5. Map source

6. https://www.iucnredlist.org (retrieved on $30^{\text {th }}$ September 2018).

7. C. S. Luthin, "Status of and conservation priorities for the world's stork species", Col. Water birds 10, pp. 181-202, 1987.

8. Elliott, Family Ciconiidae (Storks). Pp. 441-442 in J. del Hoyo, A. Elliott and J. Sargatal, eds. Handbook of the birds of the world. Volume1. Barcelona: Lynx Edicions, 1992.

9. R. Rahmani and S. Javed, "Ecology and distribution of Indian storks with special reference to endangered species". Project Report. Department of Wildlife Sciences, Aligarh Muslim University, 1999.

10. D.Chevallier, F. Baillon, J.P. Robin, Y. Le Maho, and S. Massemin-Challet, Prey selection of the Black Stork in the African wintering area. J. Zool. 276, pp. 276-284, 2008.

11. D.Chevallier, Yvon Le Maho , F. Baillon, R. Duponnois ,C. Dieulin, P. Brossault , P. D. Franclieu, P. Lorge, A. Aurouet \& S. Massemin, "Human activity and the drying up of rivers determine abundance and spatial distribution of Black Storks Ciconia nigra on their wintering grounds", Bird Study, 57 Vol.3, pp. 369-380, 2010.

12. K. S. G. Sundar, "Flock Size, Density and Habitat Selection of Four Large Water birds Species in an Agricultural Landscape in Uttar Pradesh, India: Implications for Management", Waterbirds: The International Journal of Waterbird Biology, 29 Vol.3, pp. 365-374, 2006.

13. J.D. Hoyo, A. Elliott and J. Sargatal, Handbook of the Birds of the World. Ostrich to Ducks. Family:
Ciconiidae (Storks). Vol. 1. Lynx Edicions, Barcelona, Spain, 1992, pp. 696,

14. S. Ali, and S.D. Ripley, Handbook of the birds of India and Pakistan, Divers to Hawks. Vol. 1. Oxford University Press, New Delhi, 1978, pp. 384.

15. L.P. Poudyal, "Population status and habitat preference of Lesser Adjutant Leptoptilos javanicus in Nepal", Nagao Natural Environment Foundation Newsletter 18, pp.30-32, 2009.

16. J. Burger, S. A. Carlucci, C. W. Jeitner, and L. Niles, "Habitat choice, disturbance, and management of foraging shorebirds and gulls at a migratory stopover," Journal of Coastal Research, vol. 235, no. 5, pp. 1159-1166, 2007.

17. S. K. Robinson, Thompson III, F.R., Donovan, T.M., Whitehead, D.R. and J. Faaborg, "Regional forest fragmentation and the nesting success of migratory birds", Science 267, pp.1987-1990, 1995.

18. D.R. Norris, P.P. Marra, T.K. Kyser, T.W. Sherry and L.M. Ratcliffe, "Tropical winter habitat limits reproductive success on the temperate breeding grounds in a migratory bird", Proc. R. Soc. Lond. 271, pp. 59-64, 2003.

19. E. Sande, S. Evans, P. Newbery, P. Buckley, P. Donald \& D. Hoffmann, Action Plans for the Conservation of Globally Threatened Birds in Africa Species Action Plan Development Manual. Birdlife International, 2005.

20. C.H. Sekercioglu, "Increasing awareness of avian ecological function", Trends in Ecology and Evolution, 21(8), pp.464-471, 2006.

21. C.J. Whelan, D.G. Wenny, R.J. Marquis, "Ecosystem services provided by birds", Annals of New York Academy of Science, 134, pp.25-60, 2008.

22. J.M. Thiollay, "The role of traditional agro-forests in the conservation of rain-forest bird diversity in Sumatra", Conservation Biology, 9, pp.335-353, 1995.

23. R. Greenberg, P. Bichier and J. Sterling, "Bird populations in rustic and planted shade coffee plantations of eastern Chiapas", Mexico. Biotropica, 29, pp.501-514, 1997.

24. J.B. Hughes, G.C. Daily, P.R. Ehrlich, "Conservation of tropical forest birds in countryside habitats", Ecology Letters, 5, pp.121129, 2002. 